\title{
Role of Monetary Policy in Economic Development of Pakistan
}

\author{
Mohammad Salih Memon \\ Assistant Professor, Department of Business Administration* \\ saleh.memon@salu.edu.pk \\ Dr. AsadRazaAbdi \\ Assistant Professor, Department of Economics* \\ Mr. SarmadRahat \\ Lecturer, Department of Economics* \\ *Shah Abdul Latif University Khairpur, Sindh, Pakistan
}

\section{Abstract}

\begin{abstract}
The aim of conducting this study was to look at the position of monetary assets in the perspective of economic development, data was collected from the ministry of finance government of Pakistan, and State Bank of Pakistan from (2000-01 to 2009-10) and linear regression was applied through SPSS 16 and concluded the position of imports and exports, that increase in exports will be the reason for increase in monetary assets of the country and same as increase in imports will also be the reason of increase in monetary assets in the shape of taxation, consumer price index is affecting negatively on the monetary assets in the way that when CPI is increasing the monetary assets available in the economy is decreasing always, finally if governments are trying to enhance the monetary assets in the economy they must relax the trade policy and tight control on inflation
\end{abstract}

\section{Council for Innovative Research}

Peer Review Research Publishing System

Journal: International Journal of Management \& Information Technology

Vol. 10 No. 2

editorsijmit@gmail.com

www.ijmit.com/ojs 


\section{Introduction}

A lucid and straight link among budgetary plan and growth has been coupled with the taxation plan. One connection is built on the initiative that levies are not impartial (in language of classified economic agent's allocation decision). Therefore, distortions are introduced in to the financial system. A subsequent connection is using the brunt of taxation on aspect amassing, predominantly capital. And it relates near the excessive saddle of tax in vibrant sense. A different conduit typically recommended in the writing is the stipulation of tax incentive in favor of promoting venture, research and expansion behavior (Tanzi \& Zee, 1997).An important feature of the study conducted especially on poverty in Pakistan starting with the (Naseem, 1973) pioneering work, is with rare exceptions, almost all have concentrated on estimation of levels of poverty without addressing the major policy issues.Despite of several fiscal measures introduced since the inception of Islamic Republic of Pakistan but the growth has not accelerated as in our neighbor countries and economic development remains wide spread and pervasive, in the Pakistan. This research will contribute to the economy of Pakistan in a way that how best to increase/improve the level of Economic development in the country.

Researcher is sure regarding the achievement of objectives than we will be beneficial in the way that:

- the deficit can easily be decreased from the budget

- $\quad$ taxation policies will must be influential

- $\quad$ And ultimately our surplus amount will be invested in productive activities for which our GDP, exports, and Reserves will grow.

Monetary Assets: a plus point such like cash, account receivable/a note receivable wherever the quantity is unchanging, and affirmed amount, while governments are holding these belongings for the duration of the periods of price increases will outcome in failure of purchasing authority. The pecuniary assets are known as (M2), and consist of:

1. Money in transmission

2. Exact deposits

3. Instant deposits, and

4. Resident's foreign currency

Table: Monetary Aggregates

\begin{tabular}{|c|c|c|c|c|}
\hline & & & & s. Million) \\
\hline Items & End. & & July & May \\
\hline & 2011 & 2012 & $2011-12$ & $2012-13$ \\
\hline A. Currency in Circulation & $1,501,409$ & $1,673,746$ & $1,671,894$ & $1,935,248$ \\
\hline Deposit of which: & & & & \\
\hline B. Other Deposits with SBP & 10,145 & 8,899 & 12,031 & 10,738 \\
\hline C. Total Demand \& Time Deposits incl. RFCDs & $5,183,640$ & $5,959,150$ & $5,592,433$ & $6,401,614$ \\
\hline of which RFCDs & 374,945 & 440,130 & 412,240 & 505,960 \\
\hline Monetary Assets Stock (M2) A+B+C & $6,695,194$ & $7,641,795$ & $7,276,358$ & $8,347,600$ \\
\hline Memorandumbitems & & & & \\
\hline Currency/Money Ratio & 22.4 & 21.9 & 23.0 & $\overline{23.2}$ \\
\hline Other Deposits/Money ratio & 0.2 & 0.1 & 0.2 & 0.1 \\
\hline Total Deposits/Money retio & 77.4 & 78.0 & 76.9 & 76.7 \\
\hline RFCD/Money ratio & 5,6 & 5.8 & 5.7 & 6.1 \\
\hline Income Velocity of Money & 2.9 & 2.9 & 2.7 & 2.7 \\
\hline
\end{tabular}

Source: State Bank of Pakistan

\section{Economic Development Variables}

Un-Employment Rate: the percentage of total labor force that is un-employed but actively seeking employment and willingness to work. A global economic turmoil has been the reason of unemployment in the globe plus inside Pakistan 2.93 million of labor force is unwaged, it may be the mismatch in the job and skill of labor force and most of the temporary nature of jobs creates the problematic situation.

Health \& Nutrition: health is the main part of human well-being and had lots of economic benefits. Pakistan is one amongst the 115 countries in the world which recognizes the legal right of health facility. In Pakistan, the health status of the total population at large scale has improved considerably, but as far as international comparison is concerned, position is mixed, but in general there are the improvements.

Exports: to send or shipped the commodities abroad, especially for the purpose of sale. The target of Pakistan was $\$$ 24.8 billion or simply said that $4 \%$ higher than last year for $2012-13$.

Imports: to bring goods and materials in from other sources, especially from other countries for the trade. Import growth of Pakistan become slow and showing negative growth of $1.02 \%$ during staring ten months of current fiscal year. 
CPI: CPI is a gauge of subjective standard of prices of case of supplies or services demanded by consumers for example: transportation, food and etc. The CPI can easily be calculated by collecting price changes for the items of specific group and averaging them, but the importance of the goods create the weight accordingly. CPI is most commonly used statistical method for knowing the times of inflation or deflation. It is only because of high increase of CPI in short period is known as era of price increase, plus high cut in CPI into squat era is usually known as periods of deflation.

Investments: any asset or good purchased with the expectation that it will yield income. In the economic sense purchase of goods for use in coming future for creation of wealth is known as investment. And investment is a monetary asset purchased for the purpose that it will provide income and gain at the time of sale; is about the financial sense. Investment can proceed through two different ways; (direct investment and indirect investment). Investment got the main role in determining the economic growth of any country, and productive capacity can only be enhanced by the investment and will lead to the employment opportunities. Investment depends upon the number of other factors that is why it is the reason of major fluctuations in GDP.

\section{Literature Review}

In the dynamic monetary plan system interest rate rises, if price rises more than the intention plus fiscal plan stabilizes the government debt, and on other hand in reflexive policy management fiscal plan is not self-alleviated, genuine interest rates must be condensed for stabilization if level of inflation is too much high (Lewis \& Leith, 2000).

Same as the relationship of both policies (monetary and Fiscal) in macroeconomic stabilization have also been inspected by (Lambertini, L; Rovelli, R, 2003) analyzed Stake berg equilibrium, and they suggest three cases for taking inventiveness to reserves, government, along with centralized banking authority in carrying out of policy procedures. And accomplished that preferable plus feasible result is that there is single authority in the policy game of macroeconomy is the fiscal authority.

(Zoli, 2005) Also initiate that nearby fiscal supremacy in Brazil plus Argentina, discovered that fiscal plan events have contribution to fluctuations in exchange rate more than unanticipated maneuvers of monetary policy, trying to establish the reality that fiscal plan affect the monetary variables.

(Agha \& Khan, 2006) completed that price rises is the fiscal incident, and described that fiscal plan is significantly influencing the behavior of monetary policy, and for the improved performance of economy coordination between policy makers is mandatory.

A survey conducted by (Ploeg, 2004) for various views on the fiscal policy role and debt of government in determining macroeconomic outcomes. In starting researcher assess classical and Keynesian views regarding effects of demand and supply side policies on total employment, national income, components of overall demand and rate of interest by giving concentration to automatic stabilizers, crowding out the dynamics and price. And then researcher examined the implications of long-run for public consumption and government debt for economic growth rate, and concluded in the light of current macroeconomic outlook.

The global financial calamity that arises about September 2008, fiscal plan of India was being veteran through three main channels by (Kumar \& Soumya, 2010):

1. Contagion risk to financial segment

2. The pessimistic impact on exports,

3. Effects on exchange rates.

According to (Jha, 2007) a broad view of fiscal issues confronting developing countries, three amongst are:

1. Emergent countries have small tax/gross domestic production plus spending/gross domestic production ratios as compare to urbanized countries, even while.

2. Fiscal stance of developing countries is pro-cyclical

3. Tax resources of developing countries are more volatile than developed countries.

Researcher also considers the issue of budget deficit and problems of budget deficit in developing countries, and also discussed some widely accepted tax norms, and expenditure reforms as an issue of intergovernmental transfers in federal developing countries. And concluded that there is important and complex position of fiscal plan in developing countries and those countries are facing unenviable task of accelerating their economic growth rate for reduction of poverty in a short span of time even though they face huge uncertainty in the face of globalization, about the key factors of their fiscal policy, such as tax base.

Regrettably what is measured as a Keynesian plan today is principally misconception of the prescription of Keynesian, which mainly trunk from the essential misidentification of the theory of effective demand with the theory of aggregate demand (Tcherneva, 2011).

Research of (Kakar, 2011) determined the impact of fiscal erratic on economic expansion of Pakistan via time series information 1980-2009, co integration and error correlation techniques were used for analysis for determining the route of causality, cram provided help in exploring the significance of fiscal plan for expansion of Pakistan, and concluded that fiscal plan affect the long-run economic development, and fiscal plan is very imperative for sustainable economic expansion in Pakistan, plus fiscal plan dealings mostly of long-run observable fact rather the short-run. Because in shortrun economic expansion can be geared up through scheming interest rates along with the expenditure of government at the cost of inflation. But that type of plan might affect the velocity of economic growth progression. 
(Gupta et. al., 2002) picked the sample data of 39 tiny income countries for 1990-2000, indicated that the incise in present spending has a major growth impact than of those which relying on increase in income along with incise in capital spending; researchers indicated that the countries where salary rate decide the model of consumption, tends to be slightest developed, and those who assign big share of capital plus non wage merchandise and services like speedy growth.

Crowding out by hypothesis for Pakistan was tested by (Hyder, 2001) used vector error correction, and indicated the subsequent association between private investment as well as public investment.

(Guess \& Koford, 1984) worked on granger causality test for identifying the fundamental connection among inflation, GNP, budget deficit as well as private investment via yearly data from 17 OECD countries for 1954-1981 and concluded that deficit budget do not be the reason of changes in the above variables.

(Aschauer, 1989) Examined the position of public capital in elucidation total factor productivity plus rate of revisit on private capital in the United State's non financial commercial sector. And set up that public capital got posative impact on marginal merchandise, plus private investment can be increased by making increase in public investment.

(Easterly, William; Schimt-Hebbel, Klaus, 1984) Indicated that in developing countries a correlation exists among fiscal deficit, and inflation, when inflation rate tends to be high than governments are trying to manage their expenditure by creating money.

Figure 3.9 Harrod-Domar Growth Model

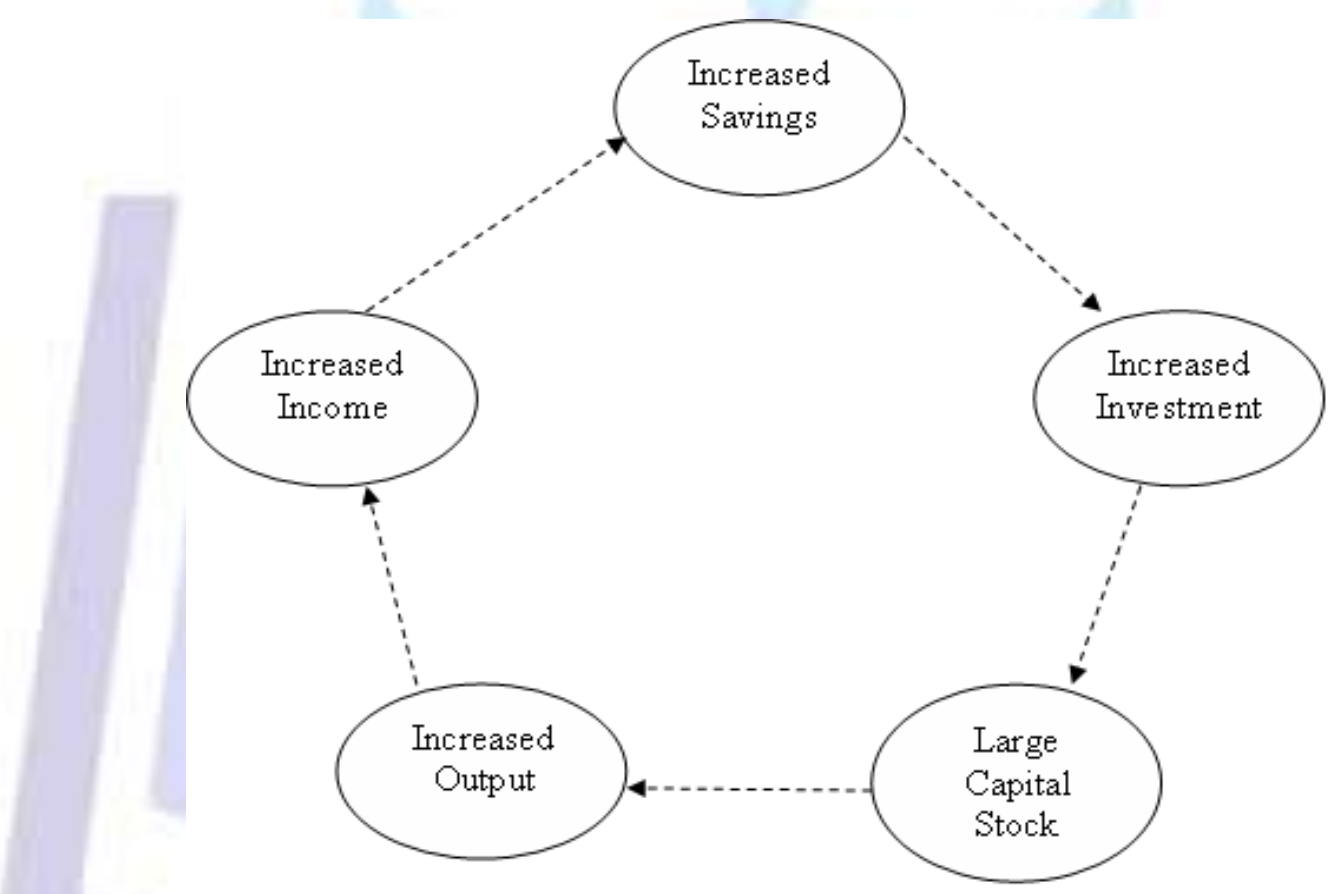

The model suggests that the growth rate of economy is depending on:

1. Level of Saving, and

2. Investment Productivity (Capital Output Ratio). 
Figure: Lewis Structural Change Model

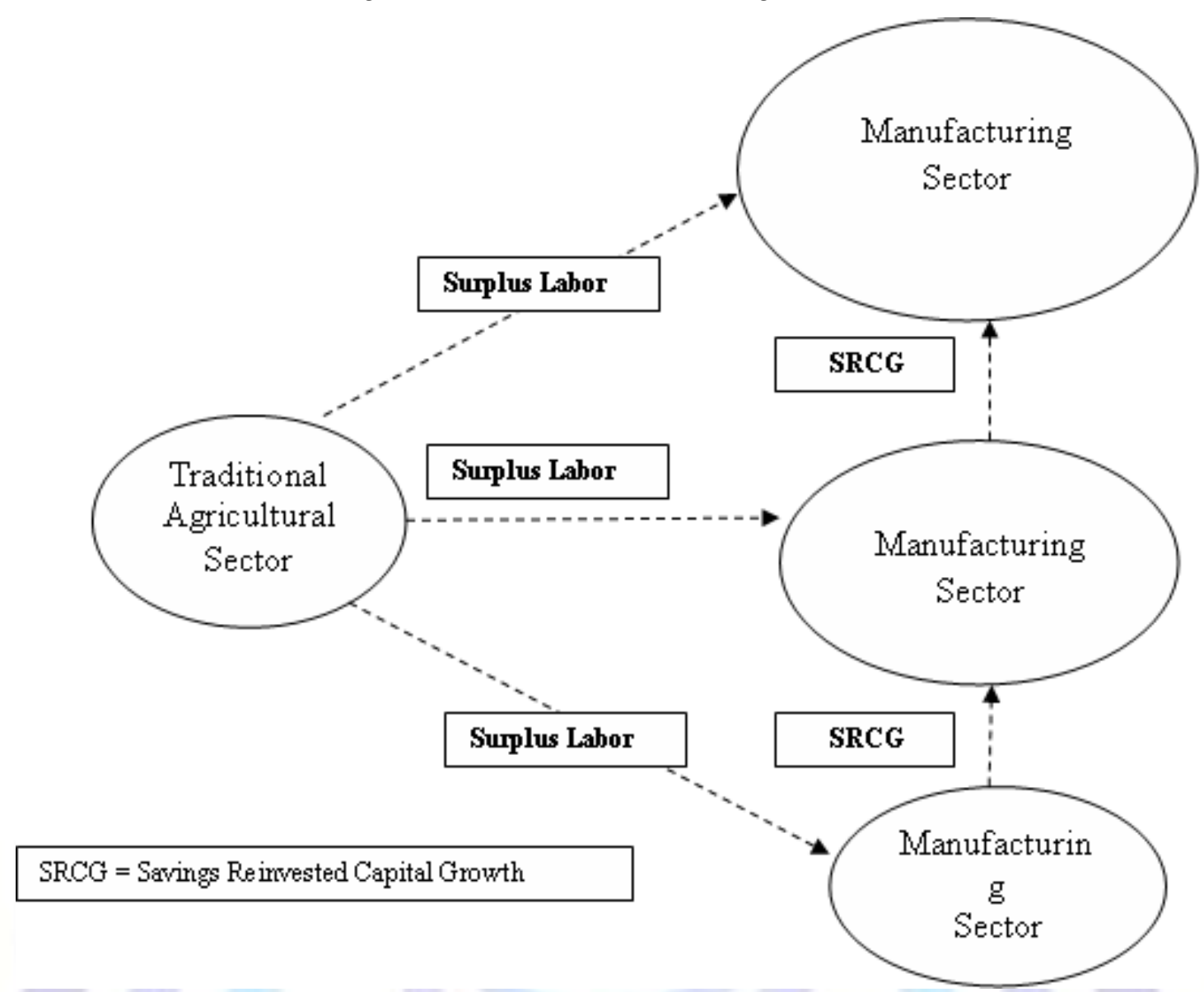

Conventional Agricultural Segment was unspecified to be survival nature, differentiated by, stumpy output, low income, low saving, and substantial unemployment.

Industrial Sector was unspecified to be mechanically sophisticated with lofty rank of investment working in the city areas.

And he suggested that the modern industrial sector would attract workers of rural areas to urban environment, and those peoples who switches from villages to towns can earn increased income:

1. Higher income can generate more saving,

2. Increased saving means additional funds on hand for investment,

3. Augmented investment means new capital and further output in developed segment.

4. Privileged wages and more incentives will move from squat output agriculture to elevated output industry and the round keep on.

\section{Methodology}

As our research is concerned: sampling methodology is followed by the most of literature available for the development and growth we almost followed them but also added some new variables of development to check the interrelationship of policy variables, with development variables, and as previously mentioned that data was collected through secondary source of information from ministry of finance government of Pakistan, and quantitative technique used for checking the above mentioned relationship is "Regression" linear, with the help of SPSS.16 (Statistical Package for Social Sciences). 


\section{Diagnostic Test}

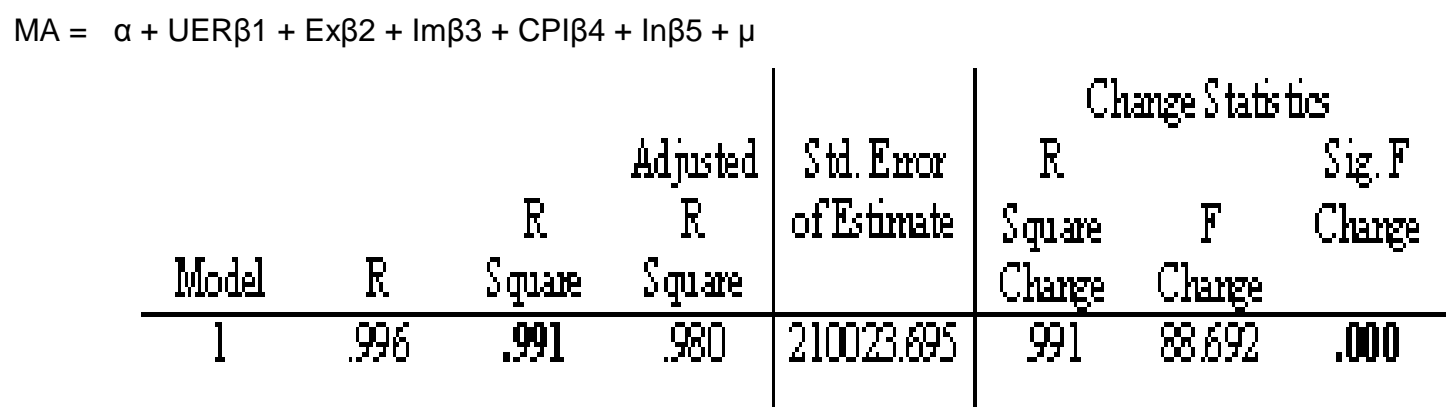

Model is properly applied and explanatory power of regression equation is greater because of the R-Square value and it is also significant at the $\mathbf{. 0 0 0}$ levels.

\begin{tabular}{|c|c|c|c|c|c|}
\hline \multirow[t]{2}{*}{ Model } & \multicolumn{2}{|c|}{$\begin{array}{l}\text { Unstandardized } \\
\text { Coefficients }\end{array}$} & \multirow{2}{*}{$\begin{array}{c}\text { Standardized } \\
\text { Coefficierts } \\
\text { Beta }\end{array}$} & \multirow[b]{2}{*}{$t$} & \multirow[b]{2}{*}{ Sig. } \\
\hline & $\mathrm{B}$ & Std. Enor & & & \\
\hline (Corstard) & 82436908 & $1526 \mathrm{E} 6$ & & 054 & .950 \\
\hline Unermployment Rate & 39900653 & 130683846 & .033 & 305 & .775 \\
\hline Exports & 2.732 & 3325 & .667 & 821 & .458 \\
\hline Imports & .89 & 658 & .537 & 1.352 & .248 \\
\hline Consumer Price Index & -7072623 & 24039.322 & -.187 & -.294 & .783 \\
\hline Wet Investments & .088 & 1669 & .006 & 053 & .961 \\
\hline
\end{tabular}

Looking at the beta column in the coefficients table, degree of association of independent variables namely; Unemployment Rate, Consumer Price Index, and net investments are very much week with the dependent variable (Monetary Assets), and somehow strong and positive association of imports and exports are to be observed on dependent variable of monetary policy (Monetary Assets).

\section{Conclusion}

While looking at the position of imports and exports researchers concluded that increase in exports will be the reason for increase in monetary assets of the country and same as increase in imports will also be the reason of increase in monetary assets in the shape of taxation, consumer price index is affecting negatively on the monetary assets in the way that when $\mathrm{CPI}$ is increasing the monetary assets available in the economy is decreasing always, finally if governments are trying to enhance the monetary assets in the economy they must relax the trade policy and tight control on inflation

\section{References}

1. Agha, A. I., \& Khan, M. S. (2006). An Empirical Ananlysis of Fiscal Imbalances and Inflation in Pakistan. SBP Research Bulletin 2(2).

2. Aschauer, D. A. (1989). Does Public Capital Crowd Out Private Capital? . Journal of Monetary Economics vol.24 , 171-188.

3. Easterly, William; Schimt-Hebbel, Klaus. (1984). Fiscal Deficit and Macroeconomic Performance in Developing

4. Countries. The World Bank Research Observer vol.2, 211-237.

5. Guess, G., \& Koford, K. (1984). Inflation, Recession, and the Federal Budget Deficit (or, Blaming Economic Problems on a Statistical Mirage). Policy Science Vol. 17, 385-402.

6. Gupta, e. a. (2002). Expenditure Composition, Fiscal Adjustment and Growth in Low-Income Countries. IMF Working Paper No. 02/77.

7. Hyder, K. (2001). Crowding-Out Hypothesis in a Vector Error Correction Framework: A Case Study of Pakistan. The Pakistan Development Review 40(4) , 633-650.

8. Jha, R. (2007). Fiscal Policy in Developing Countries: A Synoptic View. ASARC Working Paper 2007/01 . 
9. Kakar, Z. K. (2011). Impact of Fiscal Variables on Economic Development of Pakistan. Romanian Journal of Fiscal Policy 2(2) , 1-10.

10. Kumar, R., \& Soumya, A. (2010). Fiscal POlicy Issues for India After the Global Financial Crisis (2008-2010). Asian Development Bank Institute, Working Paper No. 249.

11. Lambertini, L; Rovelli, R. (2003). Monetary and Fiscal Policy Coordination and Macroeconomic Stablization: A Theoretical Analysis. Working Paper 464 Dipartimento Scienze Economiche, Universita di Bologna .

12. Lewis, S. W., \& Leith, C. (2000). Interactions between Monetary and Fiscal Policy Rules. The Economic Journal, 110 (462), 93-108.

13. Naseem, S. M. (1973). Mass Poverty in Pakistan: Some Preliminary Findings. The Pakistan Development Review , 12:4, 317-360.

14. Ploeg, F. V. (2004). Macroeconomics of Fiscal Policy and Government Debt. Journal of Economic Literature .

15. Tanzi, V., \& Zee, H. H. (1997). Fiscal Policy and Long run Growth. IMF Staff Papers , 44,179-202.

16. Tcherneva, P. R. (2011). Fiscal Policy Effectiveness: Lessons From the Great Recession. Levy Economics Institute of Bard College, Working Paper No. 649.

17. Zoli, E. (2005). How Does Fiscal Policy Affects Monetery Policy in Emerging Market Countries? BIS Working Papers 174 Bank of International Settlement. 